\title{
Explanations for the development of a novel universally inside pipe separator for dismantling (contaminated) pipelines
}

\author{
Madeleine Bachmann and Sascha Gentes \\ Karlsruhe Institute of Technology (KIT) - Institute for Technology and Management in Construction (TMB), \\ 76131 Karlsruhe, Germany
}

Correspondence: Madeleine Bachmann (madeleine.bachmann@kit.edu)

Published: 10 November 2021

\begin{abstract}
During the operation and dismantling of nuclear facilities, individual pipelines must always be removed due to leaks because of the end of their maximum service life or the dismantling of the plant. In practice, this activity, which at first glance appears simple, is associated with many challenges due to limited space or the fact that the pipelines run through walls, despite various solutions that are available on the market. Therefore, the aim of the joint research project "RoTre" (Development of a novel universally inside pipe separator for dismantling contaminated pipelines) between KIT, Siempelkamp NIS Ingenieurgesellschaft mbH and RWE Nuclear $\mathrm{GmbH}$ is the development of an innovative and competitive inside pipe separator for use in decommissioning and dismantling of nuclear facilities with a wide range of applications for various pipe diameters, wall strengths and materials (Fig. 1). An amendment will be the forward cleaning, whereby metal chips or other components can be captured continuously. Besides the dismantling in areas which are difficult to access, such as pipelines set in concrete or pipelines that cannot be drilled over their full length, dismantling should be possible in air and under water. After application, the system can be decontaminated.

In order to separate pipes made out of different materials with various wall thicknesses, the development of a universally applicable test stand is planned in order to achieve the scientific work objectives. Among other things, it should be determined whether a sawing or an abrasive cutting process is more suitable for cutting inside pipes. Building on this, the parameters of the separation process are tested in a parameter study to achieve the smallest possible process forces with a universal applicability. Relevant parameters are the geometry parameters of the cutting unit like the saw tooth shape, the composition of the cutting wheel, as well as the process parameters in the form of infeed, cutting speed and tool speed. The cutting quality achieved by the different tools with the setting of the machine parameters is also an evaluation criterion for the selection of the cutting process.
\end{abstract}

Kurzfassung. Beim Betrieb und Rückbau von kerntechnischen Anlagen müssen immer wieder einzelne Rohrleitungen oder Rohrleitungsbündel aufgrund von Leckagen, des Erreichens ihrer maximalen Lebensdauer oder der Demontage der Anlage entfernt oder ersetzt werden. In der Praxis ist diese auf den ersten Blick simpel erscheinende Tätigkeit, infolge von beengten Platzverhältnissen oder dem Verlauf von Rohrleitungen durch Wände, trotz diverser auf dem Markt existierender Lösungen, mit vielfältigen Herausforderungen verbunden. Ziel des gemeinsamen Forschungsprojektes „RoTre“ (Entwicklung eines neuartigen, universellen Rohrinnentrenners für die Demontage von kontaminierten Rohrleitungen) des KIT, der Siempelkamp NIS Ingenieurgesellschaft $\mathrm{mbH}$ und der RWE Nuclear $\mathrm{GmbH}$ ist daher die Entwicklung einer innovativen und wettbewerbsfähigen Rohrinnentrennvorrichtung für den Einsatz bei der Stilllegung und dem Rückbau kerntechnischer Anlagen mit einem breiten Anwendungsspektrum für unterschiedliche Rohrdurchmesser, Wandstärken und Werkstoffe (Abb. 1) Zusätzlich zum reinen Trennen und Abtransportieren der Leitungen ist zudem vorgesehen eine Möglichkeit für einen vorlaufenden Reinigungsvorgang zu entwickeln. Anfallende Späne oder andere Reststoffe sollen dabei kontinuierlich abgesaugt werden. Neben der Demontage schwer zugänglicher Rohrleitungen 
(beispielsweise einbetonierte, nicht auf voller Länge überbohrbare Leitungen) soll die Demontage sowohl an Luft als auch unter Wasser möglich sein. Zum flexiblen Einsatz soll die Bedienung als auch das Einbringen in das zu trennende Rohr manuell oder fernhantiert erfolgen können. Das System ist dabei so konzipiert, dass es nach einer Anwendung dekontaminiert werden kann, um es universell einsetzen zu können.

Zur Trennung von unterschiedlichen Werkstoffen sowie Wandstärken ist zur Erreichung der wissenschaftlichen Arbeitsziele die Entwicklung eines universell einsetzbaren Versuchsstands vorgesehen. In diesem soll unter anderem ermittelt werden, ob sich ein Säge- oder Trennschleifverfahren besser für die Rohrinnentrennung eignet. Darauf aufbauend werden in einer Parameterstudie die Kenngrößen des Trennverfahrens zur Erreichung möglichst kleiner Prozesskräfte bei universeller Einsetzbarkeit erprobt. Relevante Parameter sind hierbei die Geometrieparameter der Trenneinheit, beim Sägen wäre das die Sägezahnform, beim Trennschleifen die Zusammensetzung der Trennscheibe, sowie die Prozessparameter in Form von Zustellung, Schnittgeschwindigkeit und Werkzeugdrehzahl. Ebenso stellt die erreichte Schnittqualität der unterschiedlichen Werkzeuge unter Einstellung der Maschinenparameter ein Bewertungskriterium für die Wahl des Trennprozesses dar.

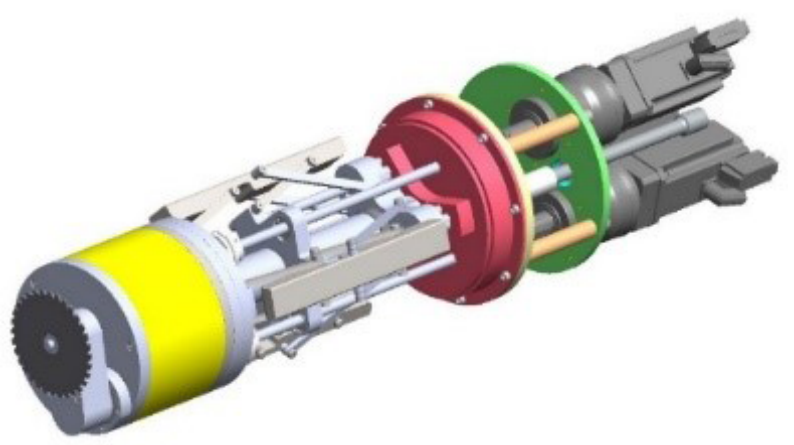

Figure 1. Schematic rough concept of the planned separation device (Siempelkamp NIS Ingenieursgesellschaft mbH). 